\title{
Przeciw metodologii?
}

\section{Monika Kłosowska}

\author{
Uniwersytet Warszawski
}

\begin{abstract}
[Artkuł ukazał się wcześniej na łamach InterAliów w sekcji artykuły bieżące, tutaj.]
W artykule przygladam się krytycznie swojemu procesowi badawczemu opartemu na wywiadach swobodnych z osobami o doświadczeniu życia jako kobiety. Rewiduję powzięte wcześniej postanowienia, inspirując się już nie tylko metodologia feministyczna, ale przede wszystkim teoria queer. Sporo miejsca poświęcam problemom etycznym zwiazanym z relacja badaczka-badana, w szczególności sytuacjom gtębokiej zażyłości czy więzi seksualnych, jakie moga występować w tym układzie przed, w trakcie czy po realizacji wywiadu. Zainspirowana doświadczeniami akademiczek i akademików spoza Polski docieram do momentu, w którym jedynie ujawnienie kontekstu rozmowy, w formie komentarza, oraz publikacja catego wywiadu, bez jakichkolwiek interwencji z mojej strony moga uczynić relację mniej hierarchiczna, wciąż jednak nie na tyle, by w zupetności pozbyć się moralnych dylematów towarzyszącym badaniom społecznym.
\end{abstract}

Słowa kluczowe: socjologia, metodologia queer, autoetnografia, etyka, niehierarchiczność

\section{Pierwsze kroki i pierwsze porażki}

Kiedy dwa lata temu rozpoczynałam swoje badania, mierzyłam się z potrzebą przeprowadzenia ich z jednej strony możliwie rzetelnie, a więc w oparciu o znaną mi technikę badawczą, w tym wypadku wywiad swobodny; z drugiej strony zależało mi, aby perspektywa queer, obecna jako pewna rama teoretyczna, ale też moja osobista optyka wynikająca z doświadczenia, stanowiła solidny fundament samego badania, wskazując mi nie tylko kierunek interpretacji, ale także sposoby działania. Swoje poszukiwania metodologii queer opisałam w artykule Działaczka czy badaczka? Przymiarki do metodologii badań w świetle teorii queer (Kłosowska 2012) ${ }^{1}$, tam też przyglądałam się propozycjom akademiczek i akademików, których zajmował podobny temat (Braidotti 2009; Hammers, Brown III 2004; Haraway 1991; Ramazanoglu, Holland 2002; Scales 2009). Niepewna mającego się rozpocząć procesu zbierania danych zakończyłam tekst postawieniem kilku pytań, głównie natury etycznej, oraz optymistycznym postulatem, że warto spróbować. Dziś, po zrealizowaniu czternastu wywiadów swobodnych oraz jednego grupowego wiem, że metodologia queer wciąż pozostaje dla mnie wyzwaniem, a rola badaczki, jaką próbowałam odgrywać, nastręczała wątpliwości, których w toku pracy, wbrew pozorom, nie ubywało. Dylematy, które pojawiały się w trakcie prowadzenia badania i po jego ukończeniu stanowić będą pierwszą część niniejszego artykułu, bowiem to one skłoniły mnie do dalszych poszukiwań perspektyw badawczych, innych aniżeli te, na których bazowałam przed rozpoczęciem badań. Kolejno przedstawię punkty, które przyjęte a priori, okazały się niemożliwe do

${ }^{1}$ W artykule krytycznie odniosłam się do pozytywistycznych postulatów realizowania badań społecznych. Analizowałam różne perspektywy feministycznych metodologii badań, które wydały mi się bliskie i adekwatne w planowanym procesie badawczym. Poszukiwania odpowiedniej metody badań oparłam na wykazaniu punktów zbieżnych pomiędzy metodologiami feministycznymi a perspektywą queer, sięgnęłam po nowe rozwiązania (zasady tworzenia queerowego porno). Ponadto uzasadniłam wybór techniki, krótko rozważając wady i zalety wywiadu. Sporo miejsca poświęciłam rozmyślaniom nad nierównością wpisaną w układ badaczka-badana i szukaniu rozwiązań, które pozwoliłyby oddać jak najwięcej przestrzeni, wypracowanym na wspólnych zasadach, osobistym narracjom, a jednocześnie pozwoliły krytycznie spojrzeć na uprzywilejowaną pozycję "reprezentantki nauki”. 
zrealizowania, a przynajmniej niezwykle trudne. Opowiem o zastrzeżeniach, które do mojego warsztatu wniosły same badane. Podzielę się refleksją nad moją rolą jako prowadzącej badanie społeczne oraz zaprezentuję wnioski, które skłoniły mnie, aby zebrany materiał badawczy pozostawić niemalże nietknięty.

Rozpocznę od wybranych aspektów, które w poprzednim tekście, zainspirowana zasadami tworzenia queerowych filmów porno, potraktowałam jako wskazówki dla badaczki realizującej wywiady. Pierwsza z nich - włączanie - dotyczyła otwartości na istnienie nieograniczonej liczby tożsamości, także tych zmiennych, niejasnych oraz ich braku. Dla mnie oznaczało to nie tylko swobodę w definiowaniu się osób, z którymi rozmawiałam (na tym polu nie mam sobie nic do zarzucenia), ale wręcz implikowało płynne, umowne identyfikacje. O ile w trakcie wywiadów udawało nam się wytworzyć przestrzeń odpowiednią, aby ten temat pogłębić, o tyle w procesie poszukiwania chętnych pojawiły się komplikacje. Po pierwsze, zaproponowana przeze mnie metoda doboru osób w postaci otwartego listu rozsyłanego różnymi kanałami okazała się niewystarczająca. I choć bardzo chciałam wierzyć, że po jego przeczytaniu osoby zwyczajnie zgłoszą się do mnie, w rzeczywistości była to dopiero forma nawiązania kontaktu, po której następowało pytanie "czy się nadaję?" lub "możemy porozmawiać, jeśli uważasz, że to mogę być ja". Autodefinicja, połączona z brakiem kryteriów, których spełnienie kwalifikuje (bądź nie) do udziału w badaniu, w moim odczuciu możliwie jak najbardziej inkluzywna forma, najwidoczniej stanowiła dla niektórych ludzi niejasny komunikat, który wymagał potwierdzenia "ekspertki", co stawiało mnie w sytuacji, w której zupełnie nie chciałam się znaleźć. W dodatku w samej treści zaproszenia znalazło się słowo „kobieta”, którego użycie motywowałam chęcią realizowania wywiadów z osobami mającymi doświadczenie życia jako kobiety, bądź socjalizowanymi do roli kobiet (takie bowiem było moje założenie); słowo to w konsekwencji wywołało wątpliwości, ale, na szczęście, udało mi się je wytłumaczyć. Ostatecznie dałam się złapać w pułapkę kategorii, dodatkowo formułując stosunkowo ekskluzywne zaproszenie (wbrew kolejnej zasadzie - dostępności), czego, być może, konsekwencją była konieczność osobistego namawiania wybranych osób do uczestnictwa w badaniu.

Kolejna ważna zasada - zgoda - miała określać, mówiąc ogólnie, zasady współpracy między badaczką, a osobą, której życie było badane. Pamiętałam więc o atmosferze w trakcie rozmowy, osobom zainteresowanym nakreślałam tematykę wcześniej, zakończony i spisany wywiad wysyłałam do autoryzacji. Dokładałam wszelkich starań, aby swoboda odbywania wywiadu swobodnego była jak największa. Pozwoliłam sobie jednak na pewną strukturę, dzieląc omawiane tematy na cztery grupy (o czym uprzedzałam w zaproszeniu, gdzie krótko je definiowałam); miało to nadać rozmowie jakiś ład, a mi, na etapie analizy i interpretacji materiału, ułatwić pracę. Wyszczególnione obszary pokrywały się bowiem z zaproponowanymi przeze mnie, na poziomie teoretycznym, przejawami zjawiska genderbending.

W praktyce podział ten nie okazał się szczególnie użyteczny, pytania i odpowiedzi powracały w sposób niekiedy zupełnie chaotyczny. Najtrudniejszym momentem był jednak ten, w którym osoba badana zupełnie go zakwestionowała. Potraktowała go jako moje założenie, nie konsensualne, nieskonsultowane z nią wcześniej, a więc niedające jej możliwości współtworzenia wywiadu. Słuszna uwaga, z której skutkami borykam się do teraz. Przede wszystkim był to ostatni wywiad indywidualny w tamtym okresie; jeśli przyszłoby mi realizować kolejne, taki podział z pewnością byłby 
uzgodniony wcześniej, o ile w ogóle zostałby utrzymany. Po drugie, komentarz ten wzmógł moje istniejące wcześniej wątpliwości co do sposobu interpretacji danych. Ostatecznie zdecydowałam się na przeprowadzenie wywiadu grupowego, w którym pytałam nie tylko o doświadczenia osób badanych, ale też poszukiwałam wskazówek metodologicznych, uwag krytycznych na temat realizacji badania jako takiego.

Ostatnią zasadą, jaką chciałabym omówić tu krótko był edukacyjny aspekt badań. Zakładała ona, że relacja budowana między stronami na potrzeby wywiadu może być okazją do wymiany, dokształcenia się, podzielenia nie tylko doświadczeniami, ale wiedzą. Tak z pewnością się stało w kilku przypadkach - informacje, jakie otrzymywałam od respondentek po badaniu, pozwalają mi myśleć, że nasze rozmowy stały się przyczynkiem do przemyśleń, weryfikacji postaw, zmiany zachowania. Niezależnie od kierunku tych przemian cieszy mnie sam fakt, że nastąpiły. Pozostaje jednak pewien niedosyt - skoro najciekawsze rzeczy wydarzyły się po wywiadach, jaką wartość ma spisany wywiad? Czy należy teraz powrócić do każdej z osób, ponownie porozmawiać? Namówić na komentarz, wspólnie zaprojektować kolejne badanie, a może pokusić się o obserwację uczestniczącą? Ciekawość, jak strategie oporu wobec kulturowej płci mogą zmieniać się w życiu konkretnych osób, kształtować i rozwijać, sprowokowane stawianymi w wywiadach pytaniami, realizować po tym, jak zostały zwerbalizowane i usłyszane przez uczestniczki badania, skłania mnie ku dalszej pracy nad tematem. Ale przede wszystkim poddaje refleksji samo narzędzie, jakim jest wywiad, eksponuje jego znaczenie dla wprowadzenia danej tematyki, nie tylko z punktu widzenia potencjalnych czytelniczek mojej dysertacji, ale również życia osób badanych. Jednocześnie jednak ukazuje słabość narzędzia, jakim jest wywiad, w dogłębnej i wyczerpującej analizie zjawisk społecznych. Szczególnie tych, które są częścią życiowych projektów, planów czy strategii ludzi.

Największym wyzwaniem okazała się moja własna pozycja w badaniach. Pytanie o bycie badaczką czy działaczką stało się mniej istotne w obliczu coraz liczniejszych refleksji nad naturą relacji łączących mnie z poszczególnymi uczestniczkami. Poniżej chciałabym omówić najważniejsze dylematy tamtego okresu oraz odtworzyć ścieżkę poszukiwań, która zaprowadziła mnie do koncepcji, które pozwoliłyby mi znaleźć uzasadnienie dla kontynuowania badań.

Moje zainteresowanie zjawiskiem genderbending od początku wiązało się z osobistymi doświadczeniami; obserwowaniem zachowań swoich i osób wokół, licznymi konwersacjami prowadzonymi w najróżniejszych okolicznościach, zainteresowaniami politycznymi grup, z którymi współpracowałam. Być może nie dość otwarcie zostało to przeze mnie powiedziane, zarówno w stosunku do siebie samej, jak i do osób uczestniczących w badaniu. Co mnie ograniczało? Miałam przecież odrobioną lekcję z feministycznych metod realizowania badań; wiedziałam więc, że partnerska relacja w badaniu dopuszcza, a wręcz domaga się, mojej wyraźnej obecności, mojego doświadczonego ciała i konkretnych poglądów, wyrażanych z osobistego usytuowania. Być może był to zwyczajny brak warsztatu, niedostateczna wiedza, która pozwoliłaby mi włączyć w badanie swoją narrację. Początkowo próbowałam więc oddać jak najwięcej przestrzeni uczestniczkom, nie sugerować, nie podpowiadać, nie konfrontować, nawet jeśli miałam o nich jakąś wiedzę. Jednocześnie niewypowiedziane tematy powracały, tak jak niektóre pytania, na które spodziewałam się uzyskać inne odpowiedzi. Dzisiaj myślę, że brak tez w badaniu, otwartość na uczestniczki czy zgoda na ich autodefinicję były pozorne; w rzeczywistości szukałam potwierdzenia swoich przeżyć i poglądów, podo- 
bieństw, legitymizacji dla własnych działań. Z prywatnych strategii oporu Pragnęłam uczynić zbiorowe, wpisujące się w szerszy ruch, grupę, której siła mogłaby dokonać społecznej zmiany. Zmiany, której sama nie byłam i nie jestem w stanie zrealizować, choć wciąż o niej marzę.

Im więcej rozmów odbywałam, tym bliższe stawało mi się zjawisko genderbending; już nie tylko je badałam, ale też uprawiałam. Zaproszono mnie nawet na debatę ${ }^{2}$, w której miałam opowiedzieć o oporze wobec genderu z p r a k t y ki, po raz pierwszy nie odwołując się do prowadzonych badań. Potem, w trakcie jednego z ostatnich wywiadów usłyszałam, że być może sporą wartość badawczą ma nie tylko to, co jest mi opowiadane, ale też wszystko wokół - moje prywatne wojny przeciwko płci kulturowej, krótkie rozmowy bez dyktafonu, liczne obserwacje, uczestnictwo w warsztatach, imprezach, działalność artystyczna. Zgodziłam się, ale było już za późno na sporządzenie solidnych notatek. Tym sposobem sięgnęłam po autoetnografię. Definiowana na wiele sposobów praktyka badawcza bywa sprowadzana do kilku założeń, takich jak - realizacja badań we własnej grupie (natywność), ukazanie kolejnych poziomów świadomości badaczki poprzez próbę głębokiego zrozumienia siebie i innych, introspekcja (w stronę rozpoznania uczuć i motywacji) czy przedkładanie osobistych historii nad analizę danych, którego celem jest pozwolenie i zachęcenie czytających do alternatywnych odczytań i wielu interpretacji (Ellis, Bochner 2000, Walford 2004).

Praktyka ta otworzyła przede mną możliwości włączenia w badanie osobistych doświadczeń post factum, pozwoliła potraktować je na równi z cudzymi, co na początku wydawało mi się ryzykowne. „Model opowiadania historii, jak w noweli czy biografii, przełamuje granicę między nauką a literaturą", mówią Carolyn Ellis i Arthur P. Bochner (2000: 746) i przekonują mnie. Niestety literacka technika opisu pozostaje poza moim zasięgiem (być może wciąż nie zwalczyłam w sobie przekonania, że nauka posługuje się językiem naukowym, proces ten jest, jak widać, żmudny. Innym powodem może być brak jakichkolwiek doświadczeń pisania prozy, paradoksalnie język "naukowy" okazuje się być mi bliższy). Rolą badaczki w autoetnografii jest redukcja zniekształceń - pisze w swoim artykule Goeffrey Walford (2004), oraz unikanie przedstawiania wyników, tak aby wyglądały jak zupełna fikcja. Refleksje te rodziły we mnie pytanie: czy te rzeczy naprawdę się zdarzyły? Czytelniczka niepewna natury twierdzeń (Walford 2004) mogłaby kwestionować przytaczane przeze mnie narracje lub formułowane wnioski tylko ze względu na formę zapisu, czego szczerze pragnę uniknąć. Walford uznaje tę metodę za przydatną przede wszystkim dla osób, które są lub będą w przyszłości zaangażowane w badanie. Sam używa podejścia autoetnograficznego do prezentacji procesu badawczego, a prywatne doświadczenia traktuje jako punkt wyjścia do dalszych badań, debat i dyskusji. Jego pogląd jest mi bliski, wobec czego, mimo pewnej fascynacji autoetnografią, zdecydowałam się wykorzystać w projekcie częściowo narzędzia, które proponuje - skorzystać z możliwości opowiedzenia o sobie w komentarzach do wywiadów, przy opisywaniu zjawiska i referowaniu teoretycznych koncepcji, pozostając przy tradycyjnej formie tekstu. W kwestii osobistych doświadczeń: jak już wcześniej zaznaczyłam, od początku projektu nie oddałam im należnego miejsca i, choć faktycznie stanowiły dla mnie inspirację, chciałabym, aby pozostały obecne w trakcie wszelkiej pracy nad dysertacją. Autoetnografia odmawia ukrywania wrażliwości czy subiektywności autorki za „socjologiczną analizą", proponuje, by eksponować je otwarcie, zwrócić się ku sobie (obserwować

2 Debata pt. "Ciało jako narzedzie polityczne" odbyła się z inicjatywy „Zielonego Jazdowa” (cykliczny projekt w parku przy Centrum Sztuki Współczesnej Zamek Ujazdowski w Warszawie)13.09.2013. 
obserwującą), próbować zrozumieć za pomocą poszczególnych narracji, jak kultura i polityka wypisane są na naszych ciałach (Ellis, Bochner 2000: 747). Genderbending to nie tylko temat, który mnie naukowo nurtuje, to także trwający proces, treść mojej codzienności; zyskał on na wartości z każdym kolejnym wywiadem, prezentacją czy wystąpieniem na konferencji. Życzyłabym sobie, aby jak najwięcej prywatnego uczynić politycznym, także za pośrednictwem pisanych tekstów.

\section{Świat (badań) bez granic!}

Dużą pomocą okazały się artykuły badaczy i badaczek, które mierzą się z możliwością queerowania metod stosowanych w badaniach jakościowych. We wstępie do publikacji Queer methods and methodologies: Intersecting queer theories and social science research (Browne i Nash 2010) Kath Browne stawia istotne pytania: jaki wpływ ma lub powinna mieć na wybory metodologiczne konceptualizacja w nurcie queer? Czy jeśli teoretyczne opracowanie jest queerowe, to metoda automatycznie też? Czy i jak można squeerować metodę badań społecznych? Szczególnie bliskie mi jest ostatnie pytanie, bowiem to właśnie próbowałam uczynić przed rozpoczęciem badań, wprowadzając do sposobu prowadzenia wywiadu swobodnego dodatkowe zasady zapożyczone z filmowej pornografii. Praktyka zweryfikowała nieco moje ambicje, dlatego z ulgą czytałam o podobnych do moich doświadczeniach innych osób. Alison Rooke (2010) swój artykuł dedykuje, między innymi, emocjom, jakie pojawiają się między uczestniczkami projektu badawczego. Badaczka ta prowadziła wywiady i obserwacje uczestniczące wśród kobiet LGB w Londynie, gdzie była znana i jednocześnie zaangażowana w działania na rzecz tej grupy. Pozwoliło jej to obnażyć fikcję i normatywność tradycyjnej etnografii, która zakłada dwa etapy pracy w terenie: głębokie relacje w trakcie badań, a następnie znalezienie odpowiedniego dystansu (przestrzennego, czasowego, emocjonalnego), by analizować i opisywać zebrane informacje. A co jeśli teren badań jest tuż obok, przenika się z życiem codziennym badaczki? Trudności z rozdzieleniem życia prywatnego i zawodowego potęgują silne emocje, powstałe w trakcie intensywnych interakcji z badanymi, na które autorka nie czuła się przygotowana przez ukończone studia czy przeczytane teksty. Moje pytanie sięga trochę dalej - co jeśli emocje istnieją już wcześniej? Jeśli wywiady odbywają się z osobami, z którymi łączą mnie bardzo konkretne relacje - współpracy, przyjaźni, dzielenia mieszkania, bycia kochankami czy partnerkami? Alison Rooke przywołuje koncepcję pracy emocjonalnej Arlie Russel Hochschild ${ }^{3}$, by pokazać, że równie ryzykowna i trudna bywa praca badaczki terenowej. Ja zaryzykowałabym tezę, że praca ta nie różni się zasadniczo, pod względem emocji, od pracy, którą wykonuję codziennie w kontakcie z drugim człowiekiem; liczba podobieństw jest zaskakująco duża - od budowania

${ }^{3}$ W swojej pracy Zarządzanie emocjami. Komercjalizacja ludzkich uczuć Arlie Russel Hochschild (2009) kreśli perspektywę włączania emocji w pracę zawodową. Na podstawie badań prowadzonych wśród stewardess dochodzi do wniosku, że specyfiką pracy postindustrialnej jest uczucie, które trafia na rynek, podlega wymianie niczym waluta, jest zarządzane i standaryzowane wedle określonych wymogów. Praca emocjonalna staje się przedmiotem wyzysku, posiada swój koszt i system rekompensat. Wynikiem takiej sytuacji jest zjawisko "transmutacji systemu emocjonalnego"; skutecznie zrealizowane owocuje skomercjalizowaniem uczuć, zgodą na narzucone reguły odczuwania, sprzedaniem emocji zgodnie z oczekiwaniem klientka/ki i brakiem poczucia fałszu i wyalienowania. Transmutacja nieskuteczna z kolei skutkuje odczuwaniem przymusu, nieszczerości w stosunku do siebie i może zakończyć się porzuceniem zajęcia, które wymaga pracy emocjonalnej. Adaptując ten przykład do zawodu badaczki należałoby spodziewać się dwu reakcji. Pierwsza zakładałaby umiejętność oddzielenia emocji pojawiających się w trakcie rozmów z badanymi, potraktowania ich jako jednego z elementów badania i zdolność łatwego powrotu do "rzeczywistości”. Druga, będąca moim doświadczeniem, charakteryzuje się trudnością z oddzieleniem emocji związanych z badaniem od innych, poczuciem nieadekwatności, koniecznością „odgrywania" poszczególnych stanów emocjonalnych (w przypadku badań społecznych byłoby to raczej ich ukrywanie). 
oczekiwań (których każdorazowo próbuję się wyzbyć), przez fascynację, rozczarowanie, złość, aż po stawanie się Inną (są takie odpowiedzi badanych, które stały się moimi odpowiedziami). Założenie, że przyjęta rola prowadzącej badanie pozwoli mi na zbudowanie dystansu nie ma racji bytu w kontaktach ze znajomymi osobami, ani przez chwilę nie daje takiego złudzenia; początkowe próby budowania atmosfery badania (intymność, odseparowanie, wcześniejsze umówienie, wyraźny początek i koniec definiujące sytuację) parokrotnie zakończyły się porażką, obnażenie faktycznych relacji łączących mnie z rozmówczyniami następowało zarówno z mojej, jak i z ich strony (więcej na ten temat w komentarzach do wywiadów). Nie udało się uniknąć sytuacji naruszenia granic. Dla Alison Rooke była to informacja, która byłaby zaledwie plotką, jeśli zostałaby zasłyszana w barze, jednak w terenie podważyła jej stabilne poczucie tożsamości badaczki. W moim przypadku stało się odwrotnie - opowiedziana (przez moją ówczesną partnerkę) na potrzeby wywiadu historia na tyle wytrąciła mnie z równowagi (już nie tylko z roli), że przestałyśmy kontynuować wywiad, a fakt ten przełożył się na naszą prywatną relację.

Przeciwko zamazywaniu granic pomiędzy binaryzmami, takimi jak realny/wirtualny czy wewnątrz/na zewnątrz występuje Tom Boelstorff (Boelstorff 2010) argumentując na rzecz "surfowania po binaryzmach", analogicznie do surfowania po fali, której kierunku nie zmienisz, masz jednak pewien wybór, twoje ruchy nie są całkowicie przez nią determinowane. Metafora ta jest dla badacza o tyle użyteczna, o ile postuluje on utrzymanie w mocy pewnych binarnych zestawień, których znaczenie w badaniu (dla wszystkich jego stron) jest istotne, tym samym są one niemożliwe do odrzucenia. We wspomnianym przypadku trudno mi jednak osądzić, czy ujawnianie jakichś informacji w wywiadzie było poprzedzone świadomością, że jego skutki mogą sięgać poza badanie jako takie. Takie sytuacje nazwałabym raczej zatarciem granicy między badaczką a badaną, a być może jej brakiem od samego początku. Z teoretycznego punktu widzenia bliższe mi będzie rozumowanie Diany Fuss (2000), która binaryzm, tu akurat wnętrze/zewnętrze, uznaje za niemożliwy do wyeliminowania, ale mający krytyczny potencjał - jego wywrócenie na drugą stronę, przenicowanie może obnażyć jego wewnętrzny mechanizm. Podążając tym tropem mogłabym więc dojść do wniosku, że moje uplasowanie się "na zewnątrz", czyli w roli badaczki, miało mnie chronić od informacji, które mogłyby mieć znaczenie dla mnie "wewnątrz" (partnerki respondentki). W tym samym czasie chciałam jednak skorzystać z przywileju, jakim jest prywatna znajomość - dowiedzieć się więcej, wnikliwiej pytać, sięgać po wiedzę z innych źródeł. Nie tylko więc nie zarysowałam granicy (ani nie zaproponowałam jej wspólnego ustalenia), ale odmówiłam ukonstytuowania swojej zewnętrznej tożsamości (Fuss 2000) w relacji do Innej, bowiem wybór którejkolwiek pozbawiałby mnie pewnych korzyści. „To, co na zewnątrz jest też zawsze obok", pisze Diana Fuss (2000), próbowałam więc przemieszczać się pomiędzy dwiema dostępnymi mi w tamtej sytuacji tożsamościami, co w konsekwencji sprawiło, że poczułam się zraniona jako osoba i nieprofesjonalna jako badaczka. Krytyczne przyjrzenie się nie tylko binarnym modelom, ale sposobom ich działania, a przede wszystkim realnym konsekwencjom ich (nie)świadomego stosowania może być interesującą praktyką intelektualną, podobnie jak dyskusja nad rozmywaniem czy przenikaniem granic. Mnie jednak nurtuje zupełnie praktyczne pytanie - jak dbać o osobiste granice w trakcie prowadzenia badań, jeśli nie sposób ich zaznaczyć w konkretnej sytuacji, nadając rozmowie taki kontekst, który będzie ją zasadniczo odróżniał od wielu takich samych rozmów prowadzonych między tymi samymi ludźmi na te same tematy? "Rozmawianie z innymi rozumiem jako wspólne doświadczenie", pisze Jamie Heckert (Heckert 2010: 51), co nie wydaje się nowym podejściem, ale później dodaje, iż kluczowa może okazać się troska 
o siebie, prezent darowany sobie, który pozwala więcej dać i więcej otrzymać. Banalne stwierdzenie, jednak w kontekście badań społecznych zyskuje ono dodatkowe znaczenie.

Użyte przez autora słowo care (tu w znaczeniu troska, opieka) przypomniało mi fragment wykładu, jaki w ramach Letniej Szkoły Seksualności, Kultur i Polityki w Belgradzie wygłosiła artystka, filozofka, psychoanalityczka i pisarka Bracha L. Ettinger. Według niej dbanie o drugą osobę (taking care of) nie jest możliwe pośrednio, wymaga połączenia i komunikacji. Taka komunikacja ma miejsce choćby w trakcie wywiadu, wobec czego dbanie powinno przebiegać w obu kierunkach, tak o siebie, jak o drugą stronę.

Jakościowe badania społeczne pełne są interpersonalnych spotkań, haptycznych połączeń między ludźmi, bliskości, rozumienia i osobistego uwikłania. Emocjonalny proces zbierania danych zależy od zmysłowego zaangażowania, które, w próbach przeniesienia i szukania sensu w ucieleśnionych doświadczeniach, traktuje uczucia poważnie. (Rooke 2010: 31)

Jeśli zatem zgodzę się na spektrum emocji w pracy badaczki, także tych niespodziewanych, a jednocześnie zadbam o siebie i swoje granice, proces ten może nauczyć mnie więcej, aniżeli opanowanie narzędzi badawczych czy solidne przygotowanie teoretyczne. Zadziwiający jest fakt, że wciąż tkwi we mnie nieufność w stosunku do własnej wiedzy, tej opartej przede wszystkim na doświadczeniu. Na co dzień bywam przecież osobą prowadzącą warsztaty, także te na temat wsparcia emocjonalnego, dobrze radzę sobie w różnego typu rozmowach, a koncepcja stawiania granic nie jest mi obca, jednak gdy przychodzi do pracy naukowej, odzywa się wciąż silny podział na teorię i praktykę, akademię i aktywizm i nie udaje się ani surfowanie po wspomnianych binaryzmach, ani ich odrzucenie, rozumiane jak opór bądź uwolnienie (Foucault za Boelstorff 2010: 223). Kiedy sięgam po artykuły autorek i autorów spoza Polski, ze zdumieniem czytam o tym, jak Jamie Heckert czy Alison Cooke podążają za intuicją, otwarcie mówią o swojej wiedzy czerpanej z bycia aktywistami, obnażają intymne szczegóły relacji z badanymi osobami czy kwestionują utarte schematy metodologiczne. Uczę się od nich tego, co wiem i wiedziałam już wcześniej. Pytanie o polski kontekst prowadzenia badań i otwartość akademii pozostawię jednak innym, odważniejszym.

Czym zatem byłoby queerowanie metody czy narzędzia? A może szerzej, procesu badawczego, akademii? Dla Jamiego Heckerta to queerowanie granicy pomiędzy teorią a praktyką; „teoretyzowanie jest praktyką społeczną" (Heckert 2010: 50, podkreślenie autora), o której kształcie nie decydują tylko poznane prace z dziedziny filozofii, ale myśli i uczucia wszystkich osób zaangażowanych w badania oraz osobiste uczestnictwo w różnego typu sytuacjach czy relacjach. Alison Rooke (2010: 34) wspomina o porzuceniu konwencji, które z etnografki czynią stabilny pod względem płci i seksualności nieproblematyczny podmiot. Andrew Gorman-Murray, Lynda Johnston i Gordon Waitt w artykule o formie rozmowy konkludują (2010: 112, podkreślenie autorów):

4 Wykład Brachy L. Ettinger udostępniony przez IPAK Center można obejrzeć na https://www.youtube.com/ watch?v=A3hbixTIncU (wersja dostępna na dzień 23.01.2015). 
W konsekwencji queerowanie akademii może zmienić te osoby, które realizują badania, podobnie jak produkcję wiedzy. W rzeczywistości queerowanie metodologii, w ramach i poza akademią, jest i szukaniem nowego sposobu bycia, i zmianą praktyk badawczych. [...] Queerowanie komunikacji może być przydatnym narzędziem do zrozumienia relacji władzy, tworzonych i rozbijanych w trakcie badań.

Michael Connors Jackman (2010: 125) dodaje: „Zacieranie zawodowych i prywatnych granic może być kontrowersyjne, ale mariaż akademii i życia osobistego to nie jakaś rzadkość".

\section{Wywiad za seks?}

Ostatnim aspektem queerowego spojrzenia na instrumentarium metodologiczne, jakie chciałabym przemyśleć ze względu na wyjątkową adekwatność do mojego przypadku, jest seksualna podmiotowość badaczki. W tekście The trouble with fieldwork: queering methodologies Michael Connors Jackman (2010) zauważa, że wiedza o intymnych relacjach autorki badań zwykle zaczyna się i kończy na informacji, komu i za co się dziękuje, czyje wsparcie docenia. Niewiele pozostaje miejsca na analizę specyfiki więzi, jakie mogą wytworzyć się między osobami uczestniczącymi w badaniu, choć przecież "to, co jest zapewne mniej akceptowalne, to dostrzeżenie faktu, że antropologowie i antropolożki są istotami seksualnymi - nie tylko biernymi obiektami uczuć swoich informatorów i informatorek, ale także podmiotami, które pragną" (Jackman 2010: 123-124). Autora powyższych słów skłonił ku rozważaniom na temat pożądania teren badań wyjątkowo zseksualizowany z racji dzielenia wielu doświadczeń na temat nienormatywnej seksualności w trakcie zbierania danych. Poznany podczas trwania projektu mężczyzna i stosunkowo bliskie z nim interakcje zaowocowały pytaniami: czy należałoby ograniczyć swoją ekspresję, a tym samym siebie, by móc pozostać poprawnym badaczem? Czy wejście w romantyczną relację z osobą uczestniczącą w badaniach może je skompromitować? Podobne wątpliwości ogarniały mnie wielokrotnie, choć ich przyczyna była nieco inna; ja miałam intymne (tak seksualne, jak romantyczne) kontakty z badanymi, wszystkie zostały one rozpoczęte przed realizacją wywiadów. Czy wobec powyższego powinnam była wyłączyć te osoby? Zrezygnować z potencjalnie wartościowego materiału tylko przez wzgląd na charakter związku między mną a osobą badaną? Gdzie postawić granicę zażyłości? Czy była partnerka mogłaby stać się ewentualną respondentką, ale aktualna nie powinna? Jako osoba "z wewnątrz" (por. GormanMurray, Johnston i Waitt 2010, Nash 2010), zaznajomiona ze środowiskiem badanych, od początku znajdowałam się na pozycji, która implikowała istnienie prywatnych, czasem całkiem bliskich, kontaktów z osobami, które odpowiedziały na moje zaproszenie. Znałyśmy się z niektórymi z obozu feministycznego, z inną przez jakiś czas dzieliłam mieszkanie, kolejną poznałam na konferencji naukowej. Dlaczego więc, z jakiegoś powodu, miałabym wykluczyć z tej grupy kochanki? „Problemem nie jest istniejąca erotyczna podmiotowość, ale teren badań i to, jak go konceptualizujemy w naukach społecznych", pisze Michael Connors Jackman (2010: 124), zastanawiając się, czy rozwiązaniem miałoby być zupełne zaprzeczenie istnienia erotyki w spotkaniach aranżowanych na potrzeby badań, cenzurowanie pragnień.

Zdecydowałam się na włączenie wszystkich zebranych materiałów, przy jednoczesnym ujawnieniu charakteru znajomości z każdą z uczestniczek. Osobiste relacje miały znaczący wpływ na dynamikę samego wywiadu; od doboru pytań, przez ilość odniesień do moich doświadczeń, skończywszy na 
stylu odpowiadania. Sposób budowania narracji i kształtowanie znaczenia również są pochodnymi interakcji między uczestniczkami badania (Gorman-Murray, Johnston i Waitt 2010: 101), co w praktyce oznacza, że udzielone mi w wywiadach informacje mogły (bądź nie) zostać ujawnione, odpowiednio sformułowane, nieprzypadkowo przytoczone ze względu na moją osobę i obecną między nami dynamikę. Relacje władzy, napięcia i negocjacje pozycji, niewątpliwie obecne w trakcie rozmowy, ale też przed i po, a nawet długo po zakończeniu badań, na etapie autoryzacji czy aktualizacji informacji, są dla mnie czytelne w spisanych wywiadach. Powinny być zatem ujawnione, nazwane i przeanalizowane, dostępne każdej potencjalnej czytelniczce. Z tego powodu podjęłam decyzję o opublikowaniu pod każdym wywiadem umieszczonym w dysertacji komentarza, w którym postaram się zarysować kontekst badania i możliwie uwidocznić charakter znajomości, dodatkowo odnosząc się do tego, co z punktu widzenia moich doświadczeń, wydaje się znamienne czy istotne.

Osobnym tematem, wciąż pozostającym w obszarze władzy, będzie publikowanie wywiadów. Mój początkowy zamysł opierał się na popularnej praktyce ilustrowania tez autorki wybranymi fragmentami rozmów. Wycięte z całości fragmenty, odpowiednio zestawione, dają szerokie możliwości nie tylko wzmocnienia teoretycznego wywodu empirycznym przykładem, ale stawiają mnie w pozycji osoby, która dokonuje wyboru, a więc posiada władzę nad tekstem. Oderwane od całości wypowiedzi można dowolnie wykorzystywać, tym samym zmieniając ich sens bądź nadając zupełnie nowy. Moje obawy przed tego typu manipulacją, nawet w połączeniu ze szczerymi chęciami i troską o badane, są na tyle głębokie, że jedynym dopuszczalnym rozwiązaniem wydaje mi się opublikowanie wywiadów w całości, z wyłączeniem fragmentów, które zostaną zakwestionowane przez same uczestniczki. Argument, na który zwracają uwagę Gorman-Murray, Johnston i Waitt (2010), pisząc o podmiotach z różnych grup mniejszościowych (a do takich mogłabym zaliczyć większość uczestniczek badania), które często bywają nierozumiane w społeczeństwie, co rzutuje na sposób ich komunikacji także podczas prowadzenia badań, wydaje się wzmacniać moje postanowienie; nie chciałabym, aby ewentualna czytelniczka odebrała którąś z narracji niezgodnie z motywacją respondentki tylko ze względu na brak całościowego obrazu. Nie mam i nie chcę mieć wpływu na sposób indywidualnych interpretacji przeprowadzonych wywiadów. Mogę wyrazić nadzieję, że ewentualne luki w narracji mogą zostać uzupełnione doświadczeniem własnym osoby czytającej (Walford 2004: 412), nie będą jednak wynikiem opracowania materiału przeze mnie.

Na koniec chciałabym zastanowić się nad uczuciem wstydu i jego roli w procesach decyzyjnych, jakie powzięłam. Bez wątpienia było to uczucie, które towarzyszyło mi na różnych etapach badania - od zawstydzenia przy okazji stawiania pytań, szczególnie tych dotyczących seksualności (wydawałoby się, że moje zaznajomienie z tematem pozwoli mi od tego uciec, bywało jednak, że projektowałam ewentualne skrępowanie na uczestniczki, co w wywiadach słychać wyraźnie; jedynie pytania o seks i pożądanie poprzedzone są wzmiankami typu „jeśli masz ochotę powiedzieć, jeśli chcesz się podzielić", choć przecież osoby doskonale zdawały sobie sprawę z faktu, że tematyka ta się pojawi, była ona wyszczególniona w zaproszeniu do badania), przez uczucie wstydu, kiedy podczas transkrypcji rozmów uświadamiałam sobie, że prowadzenie wywiadu nie wyglądało tak, jak sobie wcześniej założyłam, aż po wielomiesięczne rozterki, czy i jak powinnam się wyeksponować, ujawnić ze swoimi doświadczeniami i emocjami. 
Wstyd bywa odczytywany jako przeciwieństwo dumy, duma pozwala na poczucie właściwości i spójności biografii, wstyd temu zagraża (Giddens 2001), ale czy koniecznie? Ten binaryzm, podobnie jak inne, wart jest refleksji, szczególnie, że uczucie wstydu było i jest analizowane właśnie z perspektywy feministycznej czy queerowej. W artykule Kłopotliwa normalność Michael Warner (2013: 725 i n.) traktuje wstyd jako fundament budowania etyki odmieńczej: „Relacja z innym musi się zaczynać od przyznania przed samym/ą sobą do wszystkiego, co w nas samych najbardziej abiektalne i niechlubne". Koncepcja ta zasługuje przetestowania w praktyce. Co więcej, we wstydzie upatruje godności, rozumianej nie jako honor czy nabyta dystynkcja (historycznie przynależna szlachectwu, nierzadko związana z posiadaniem majątku), ale inaczej, demokratycznie i nowocześnie jako coś przyrodzonego człowiekowi, niemożliwego do nieposiadania. Tomasz Basiuk (2009: 289) dowartościowuje uczucie wstydu jeszcze bardziej, dostrzega w nim potencjał ukierunkowany do wewnątrz (w tym wypadku na badaczkę), jak i na zewnątrz (tu do potencjalnych odbiorczyń). Pierwsze działanie ma charakter autorefleksyjny, poczucie zawstydzenia, obnażenie siebie, szczere przyznanie przed sobą do wstydliwych aspektów swojego "ja", swojego zachowania może być początkiem procesu samoświadomości. Być może taki zwrot miał miejsce w moim przypadku, kiedy zamiast ukrywać się za prowadzonymi wywiadami zdecydowałam włączyć do opisu i analizy wszystko, co miało miejsce przed, w trakcie i po rozmowach. Podobnie, Carolyn Ellis i Arthur P. Bochner (2000: 748), namawiają, by zamiast uciekać od lęków i obaw, próbować się z nich uczyć, choćby dlatego, by z kolei nie wstydzić się ukrywania czy wyłączania swoich doświadczeń (co mi raczej nie grozi). Druga funkcja wstydu związana jest ze współodczuwaniem; tak uczestniczki badań, jak i ich potencjalne odbiorczynie mogą, na podstawie empatii, zainteresować się nowym obszarem doświadczenia, być może wcześniej im nieznanym bądź głęboko skrywanym.

Świadkowanie cudzemu wstydowi może, choć nie musi, prowadzić do odrzucenia narracji; bywa, że skutkuje zrozumieniem i akceptacją (Basiuk 289 i n.). Interesującej analizy wstydu dokonuje Sandra Lee Bartky w rozdziale książki Feminity and Domination. Studies in the Phenomenology of Oppression (1990), poświęconym zagadnieniu wstydu i płci kulturowej. Spośród wielu przytoczonych definicji moją uwagę zwróciła ta autorstwa Paula Sarte’a (Bartky 1990: 85): „Wstydzić się, to poddawać się ocenie jako obiektu, który pojawia się w odniesieniu do Innej". Obecność publiczności, czy to realnej, czy uwewnętrznionej, która może mnie osądzić, jest konstytutywna dla odczuwania wstydu. Kluczowe jest także rozpoznanie - "jestem" oznacza "jestem widziana, postrzegana”. I choć takie publiczności kolekcjonujemy całe życie i mam świadomość, że o żadną konkretną grupę tu nie chodzi, to w kontekście badań zastanawia mnie, kim owa Inna/Inny mogłaby być? Czy jeśli jednostka czuje się zawstydzona lub winna gdy postrzega swoje działanie jako odbiegające od standardów dla niej ważnych (Bartky 1990: 95) oznacza to, że mój wstyd dotyczy bycia nie dość doświadczoną badaczką, która decyduje się włączyć do materiału badawczego swoje osobiste, intymne przeżycia? A może wstydzę się jako osoba socjalizowana do roli kobiety, której przyszło upublicznić nie tylko emocje (co akurat wpisuje się w genderowy obraz kobiet, z drugiej strony, na gruncie socjologii, mogę sobie wyobrazić reakcje krytyczne lub niechętne takiej postawie), ale też informacje na temat cielesności i seksualności? ${ }^{5}$ Pytania pozostawiam otwarte, odpowiedzi obiecuję poszukać.

${ }^{5}$ Nie zamierzam w tym artykule dokładniej eksplorować upłciowienia wstydu. Uważam natomiast, że analiza Sandry Lee Bartky (1990) warta jest przytoczenia. Autorka porównuje filozoficzne ujęcia wstydu (także winy), sięga też to koncepcji 


\section{Podsumowanie}

Zreferowane w niniejszym tekście koncepcje pozwoliły mi przełamać metodologiczny impas ${ }^{6}$, do którego doprowadziły mnie liczne dylematy towarzyszące mi w trakcie badań. Nie jestem od nich zupełnie wolna także dziś, kiedy piszę ten tekst, mam jednak przekonanie, że znacząco mnie wzbogaciły - takie zwątpienie może wszak okazać się twórcze. Pozwoliły mi na metarefleksję, z poziomu której dostrzegłam, że stałam się dla siebie podmiotem badań: „Gdy komunikujące się jednostki studiują komunikację pomiędzy jednostkami stają się jej wewnętrzną częścią. Refleksja o tym nie powinna być brana w nawias »w imię nauki«. Powinny zostać zaadoptowane, zintegrowane z badaniem i jego produktami" (Ellis, Bochner 2000: 743). Myślę, że mogłabym się też podpisać pod wypowiedzią Susan Sontag (Cott 2014: 15):

Podoba mi się forma wywiadu - powiedziała mi pewnego razu - a to dlatego, że lubię konwersację, dialog, a znaczną część moich przemyśleń zainspirowały rozmowy. [...] Ja lubię rozmawiać $z$ innymi - unikam $w$ ten sposób zamykania się we własnym świecie, w trakcie rozmowy zaś mam okazję dowiedzieć się, co sama myślę.

Feministyczne i queerowe interwencje w metodologie badań kładą większy nacisk na procesy niż wyniki, uczą pokory, której skutkiem może być konieczność rewizji tak swoich postaw, jak i metodologicznych założeń. Nie chciałabym podporządkowywać się metodologicznym rygorom, jeśli miałyby mnie ograniczać, ale przede wszystkim dawać złudne poczucie opisu rzeczywistości. Z dzisiejszej perspektywy wiem, że wywiad swobodny jest narzędziem mocno ułomnym, szczególnie gdy nie jest opatrzony komentarzem dotyczącym relacji między jego uczestniczkami, i gdy pod opracowanymi pytaniami i odpowiedziami skrywa relację władzy niemożliwą do wyeliminowania; fragmentarycznie cytowany, a jednocześnie wciąż niezwykle popularny w socjologicznych, i nie tylko, badaniach jakościowych, zdecydowanie więcej wytwarza aniżeli odtwarza. Próby queerowania narzędzi badawczych, przyglądanie im się w sposób krytyczny, łączenie technik czy poszukiwania nowych sposobów pozyskiwania/produkowania wiedzy - wszystko to może nieco osłabić ingerencje badaczek w badaną rzeczywistość. Nie wystarczy już umiejscowiony podmiot, należy jeszcze usytuować samą metodologię (Boelstroff 2010), uwagę poświęcając temu, co na marginesie, w tle, pod spodem, co odpadło z instrukcji realizowania badań (por. Rooke 2010).

psychologicznych. Część z nich prezentuje wstyd jako emocję konstruktywną, użyteczną, której doświadczenie może uczynić człowieka lepszym, przypomnieć mu o wyznawanych zasadach. Co ciekawe, taki człowiek to Everyman, nikt szczególny, uniwersalny sprawca, na tyle uprzywilejowany w społeczeństwie, by nie tylko być ocenianym, ale móc sądzić, być definiowanym, i mieć możliwość definiowania. Wymyka się współczesnym opresjom odpowiedzialnym za liczne społeczne hierarchie, takim jak płeć, rasa, klasa. Dla takiej osoby uczucie wstydu może być zbawienne, nie jest bowiem systematycznie wyniszczana przez moralną ekonomię, w której zmuszona jest funkcjonować. Przeciwieństwem takiego anonimowego sprawcy będą wszystkie te jednostki, które podlegają opresjom. Sandra Lee Bartky postuluje analizę "moralnych emocji" (w tym wstydu właśnie) w połączeniu ze strukturą opresji.

${ }^{6}$ W tym miejscu chciałabym serdecznie podziękować dr. hab. Tomaszowi Sikorze, którego wsparcie (zarówno to naukowe w postaci podsuwanych lektur, jak i zupełnie koleżeńskie - od rozmów w podróży i przy barowych stolikach po nocne wymiany maili) okazało się niezwykle mobilizujące. 
Dużym ułatwieniem w poszukiwaniach najwłaściwszej metody oraz w staraniach nad uzasadnieniem swoich wyborów okazała się książka Paula K. Feyerabenda Przeciw metodzie (2001). Zawdzięczam jej nie tylko tytuł mojego artykułu, ale przede wszystkim możliwość inspirowania się stanowiskiem autora, które zostało nazwane przez redakcję we wstępie "sprzeciwem wobec »sakralizacji« i ponadczasowej stabilizacji jakichkolwiek norm i zasad (w szczególności metodologicznych)". Paul K. Feyerabend rozprawia się w sposób niemalże okrutny z twierdzeniami na temat nauki, z których najważniejsze dla mnie będą te broniące "nienaukowych" sposobów postępowania, odchodzenia od ścisłych reguł metodologicznych, gdyż wszystkie one posiadają ograniczenia czy krytykujące zachodni system nauczania ${ }^{7}$. Na zupełne porzucenie badań jednak się nie zdecydowałam, choć z etycznego punktu widzenia być może tak należałoby uczynić.

„Punkt widzenia stanowiący podstawę tej książki nie wynika z celowo zaplanowanego toku myśli, lecz z argumentów podsuniętych przez przypadkowe sytuacje. Siłą napędową mojej pracy był i pozostaje gniew [...]". (Feyerabend 2001: 252). W zacytowanym fragmencie znajduję realizację większości omawianych przeze mnie stanowisk teoretycznych; otwartość na rewizję, będąca wynikiem zmieniających się okoliczności (przypadkowe sytuacje), przyznanie do braku apriorycznej koncepcji, za którą należałoby podążać za wszelką cenę oraz uczucie, które jest wystarczającym powodem, by uprawiać naukę. Tym samym nie mam już wątpliwości, że mi wolno, bo jak pisał Paul K. Feyerabend anything goes. Jeśli tę anarchistyczną maksymę potraktuję nie całkiem dosłownie, jako zachętę do eksperymentowania z metodologią, to, w połączeniu z krytycznym podejściem do produkcji wiedzy (a więc i władzy, rzecz jasna), mogę sobie dać jeszcze jedną szansę na bliską relację, tym razem z akademią, i w jej ramach zakończyć rozpoczęty projekt badawczy.

\section{Bibliografia}

Basiuk, Tomasz. 2009. Obnażeni(a). Strategie retoryczne, seks i żałoba w dobie AIDS. W: (red.) Bator Joanna, Wieczorkiewicz, Anna. Ucieleśnienia II. Płeć między ciałem i tekstem. Warszawa: IFiS PAN, s. 277-309.

Bartky, Sandra Lee. 1990. Feminity and domination. Studies in the phenomenology of oppression. New York: Routledge.

Boelstorff, Tom. 2010. Two techne: queer theses on methodology and queer studies. W: (red.) Browne, Kath, Nash, Catherine. Queer method and methodologies. Intersecting queer theories and social science research. London, UK: Ashgate, s. 215-230.

Browne, Kath, Nash, Catherine J. Queer method and methodologies. Intersecting queer theories and social science research. London, UK: Ashgate.

Cott, Jonathan. 2014. Myśl to forma odczuwania. Susan Sontag w rozmowie z Jonathanem Cottem. Tłum. D. Żukowski. Kraków: Wydawnictwo Karakter.

${ }^{7}$ Choć "anarchizm teoretyczny” czy "anarchizm epistemologiczny” proponowany przez Paula K. Feyerabenda (2001) wydaje się ciekawą koncepcją, na potrzeby tej pracy wystarczy mi jedynie wspomnieć o śmiałych tezach autora, dotyczących w dużej mierze teorii nauki. Wrażenie zrobiła na mnie także forma - przez autora nazwana listem do przyjaciela. 
Ellis, Carolyn, Bochner, Arthur P. 2000. Autoethnography, personal narrative, reflexivity: Researcher as subject. W: (red.) Denzin, Norman K., Lincoln, Yvonna S. Handbook of qualitative research. London: SAGE, s. 733-768.

Feyerabend, Paul K. 2001. Przeciw metodzie. Tłum. S. Wiertlewski. Wrocław: Wydawnictwo Siedmiogród.

Fuss, Diana. 2000. Wewnątrz/za zewnątrz. Tłum. D. Ferens. W: „Furia Pierwsza. Zeszyty Gender Studies" 7.

Giddens, Anthony 2001. Nowoczesność $i$ tożsamość. "Ja" i społeczeństwo w epoce późnej nowoczesności. Tłum. A. Sulżycka. Warszawa: PWN.

Gorman-Murray, Andrew, Johnston, Lynda, Waitt, Gordon. 2010. Queer(ing) communication in research relationship: a conversation about subjectivities, methodologies and ethics. W: (red.) Browne, Kath, Nash, Catherine J. Queer method and methodologies. Intersecting queer theories and social science research. London, UK: Ashgate, s. 97-112.

Heckert, Jamie. 2010. Intimacy with strangers/intimacy with self. Queer experiences of social research. W: (red.) Browne, Kath, Nash, Catherine J. Queer method and methodologies. Intersecting queer theories and social science research. London, UK: Ashgate, s. 41-53.

Hochschild, Arlie Russel. 2009. Zarządzanie emocjami. Komercjalizacja ludzkich uczuć. Tłum. J. Konieczny. Warszawa: PWN.

Jackman, Michael Connors. 2010. The trouble with fieldwork: queering methodologies. W: (red.) Browne, Kath, Nash, Catherine J. Queer method and methodologies. Intersecting queer theories and social science research. London, UK: Ashgate, s. 113-128.

Kłosowska, Monika. 2012. Działaczka czy badaczka? Przymiarki do metodologii badań w świetle teorii queer. W: (red.) Drozdowski, Mariusz, Kłosowska, Monika, Stasińska, Agata. Strategie queer. Od teorii do praktyki. Warszawa: Difin, s. 170-185.

Rooke, Alison. 2010. Queer in the field. On emotions, temporality and performativity in ethnography. W: (red.) Browne, Kath, Nash, Catherine J. Queer method and methodologies. Intersecting queer theories and social science research. London, UK: Ashgate, s. 25-40.

Walford, Goeffrey. 2004. Finding the limits: autoethnography and being an Oxford University Proctor. W: „Qualitative Research" 4, 3. London: SAGE, s. 403-417.

Warner, Michael. 2013. Kłopotliwa normalność. W: (opracowanie zbiorowe) Teorie wywrotowe. Antologia przekładów. Tłum. M. Pelczar. Poznań: Wydawnictwo Poznańskie, s. 713-728. 